\title{
Diversification Strategy and Financial Performance of Nigeria Private Firms
}

\author{
${ }^{1}$ Ada Mac-Ozigbo, ${ }^{2}$ Dr. Cross Ogohi Daniel ${ }^{*}$ \\ ${ }^{1}$ Department of Business Administration, Faculty of Management Sciences National Open University of \\ Nigeria Abuja, Nigeria \\ ${ }^{2}$ Department of Business Administration, Faculty of Management Sciences Nile University of Nigeria,
} Abuja, Nigeria

\begin{abstract}
The relationship between diversification and firm performance varies among institutions and over time. Less is known about the advantageousness of diversification in economy-wide crises, which have occurred frequently in recent years Using data from a recent survey, we studied nearly 400 Nigeria private firms using two different approaches panel and cross-period comparisons. The findings of both approaches show that diversified firms performed better than focused firms. This was also true during the 2008 global financial crisis. The higher the diversification level, the more positive the firm performance was. We also investigated the influence of ownership structure. Firms that are totally owned by the founding owner and his/her family tend to have unsatisfactory performance under crisis. This finding provides evidence of the increasing attention on management and governance to explain firm. Linear regression models were evaluated to test the effect of diversification on firm performance. Panel A uses profit as the dependent variable, and Panel B uses sales. For each year (2007, 2008, and 2009), two regression models were evaluated: one testing the impact of diversification and the other testing the impact of the diversification level. We found that diversified firms performed better than focused firms during the recent global financial crisis. The diversification level was positively and linearly related to performance, that is, more diversified firms performed better. Moreover, we found that private firms that are totally owned by the founding owner and his/her family performed worse under crisis.
\end{abstract}

Keywords: Diversification, Strategy, Finance, Financial crisis, Performance and Private Firms.

\section{Introduction}

Diversification is a strategy that arouses continual corporate and academic interest. Corporate enthusiasm for diversification increased in the 1960s and early 1970s, but diversification went out of fashion in the 1980s and 1990s. Fortune 500 companies with at least one quarter of their revenue from diversified activities constituted $38 \%$ in 1950, $63 \%$ in 1974, and $47 \%$ in 1988. However, after the Asian and global financial crises, only the fittest survived, and some diversified companies appeared to benefit from the crises. In an analysis of 16000 companies, the Boston Consulting Group found that investors viewed diversification more favorably after the crises.

Academic interest in diversification has a long history. Studies have typically investigated the relationship between diversification and firm performance and mainly examined diversification premiums or discounts. Several studies report a discount, but others, particularly studies of emerging economies, have observed a premium. Moreover, the relationship between diversification and performance has been found to change over time. It is demonstrated a large diversification discount from 1961 to 1970, but that discount became insignificantly small from 1973 to 1976 it was found a decline in diversification premiums among Nigeria companies over time (1984-1994) and the emergence of a diversification discount from 1994 to 1996. Today, the consensus view is that the relationship between diversification and performance is environmentally dependent or institutionally contingent.

This study was designed to investigate the performance effect of diversification in an economy-wide crisis. A crisis is a high-impact event that affects the viability of organizations. Unfortunately, economy-wide 
crises are occurring more frequently than before. Management must responsibly prepare for this and diversification is a possible strategy. Currently, the knowledge gained from the contingency approach is not revealing enough, as we inhabit a turbulent world. A crisis provides a good opportunity to elucidate the relationship between diversification and firm performance, although the merits and demerits of being diversified may change dramatically in a crisis situation. Studies related to crises have focused on listed firms in developed economies. For example, Rudolph and Schwetzler (2013) studied whether diversification harms or creates shareholder wealth worldwide, including in four developed Asia-Pacific economies.

\section{Statement of the Problem}

The environment changes constantly, institutions may evolve over time and circumstances can also abruptly change in unpredictable ways. When a global crisis occurs, the financial market, domestic product market, labor market, and international trade can all change drastically, causing havoc for companies and the economy. Business scholars have examined firms' responses to major crises and found that firms of different sizes in various industries that have different ownership structures and organizations perform differently in testing conditions. However, research investigating the influence of crisis on diversification and performance is limited and appears to show conflicting conclusions.

This study extends that work to the less-explored context of private companies in Nigeria. Private enterprises are now the largest sector of Nigeria economy. At the end of 2008, they accounted for approximately $40 \%$ of the Nigeria gross domestic product (55\% of industrial output). Compared to stateowned enterprises (SOEs) and most listed firms, private firms are disadvantaged in terms of securing bank loans contract enforcement and political support. Private enterprises vary greatly but are generally smaller than most listed companies and tend to use flexibility to manage the external environment and change. Diversification may be an approach for private firms to counteract disadvantages and external challenges; economic crisis may heighten the effectiveness of diversification. Understanding how Nigeria private firms manage crisis is of interest to both academics and practitioners.

\section{Objective of the Study}

The following objective will guide this research

i. To determine the effects of diversification on the performance of Nigeria private firms

\section{Research Hypothesis}

$\mathrm{Ho}_{1}$ : Diversification has a negative effect on the performance of Nigeria private firms.

\section{Literature Review}

\subsection{Diversification and the performance of Nigerian private firms}

Environmental factors can be expected to moderate any strategy-performance relationship. During a widespread crisis, corporate behavior and performance are expected to change dramatically. Vaaler and McNamara (2004) define a crisis as a short period of unexpected and unfavorable shift in the external environment that organizations face. Pearson and Clair (1998) define such crises as high-impact events that affect organizations' viability and imply the need to make decisions quickly. Current research has explored whether diversified firms have an advantage over focused firms in economic crises.

Lubatkin and Chatterjee (1994) argue that the portfolio effect used with securities is not directly applicable to firm diversification, suggesting limited risk-spreading benefits when there are big changes in economic conditions. In their study of Nigeria firms, Chakrabarti et al. (2007) argue that diversification is associated with poorer performance during economy-wide shocks because the shock reduces the internal market benefits of diversification and increases the management and coordination costs of diversified firms.

However, Lewellen (1971) asserts that the imperfect correlation among the cash flows of a conglomerate's various businesses reduces default risk and increases the group's debt capacity relative to that of a comparable portfolio of a standalone firm. It was found that diversified firms have a lower cost of capital than their single-segment counterparts. This "more-money effect" becomes more precious during an economic crisis. Dimitrov and Tice (2006) found that, during recessions, focused firms that depend on bank financing experience an average net loss of $7.4 \%$ in industry-adjusted growth in sales compared to their diversified counterparts. 
Stein (1997) analyzed the circumstances under which the benefits of internal capital allocation are most likely to exceed their costs and found that this occurs when credit con-strains are binding. Thus, in an economic crisis, diversified firms can allocate their funds more efficiently. Kuppuswamy and Villalonga (2010) examined a panel of firms from 2005 to 2009 and found that the value of corporate diversification increased during the 2008 financial crisis. They argue that, during that crisis, diversified firms became significantly more leveraged relative to comparable, focused firms (the more-money effect) and that diversified firms significantly increased the efficiency of their internal capital allocation (the smarter money effect).

During an economic crisis, external financing becomes costlier or unavailable; this outcome increases the relative value of internal capital markets and the benefits of diversification. A setting of economy-wide crises simulates aspects of the environment of an emerging economy, particularly in terms of the difficulty of obtaining external financing. Therefore, the benefits of diversification should outweigh the costs of diversification for Nigeria private firms, especially during a crisis. Using data from Nigeria during financial crisis, it was found that firms that rely on bank debt experience less deterioration due to allaying financing constraints during a crisis period.

Diversification is not a simple strategy. It involves decisions on the type (related and unrelated) and degree (low, moderate, or high) of diversification. The linear premium model is more suitable in a less-developed institutional environment. Consistent with the traditional view that diversification can spread and reduce risk, the diversification level should relate positively to firm performance. Especially after crisis, the Nigeria Government utilizes expanded investment and credit policies to stimulate the economy. As the government investment plan has strong directivity on areas of the economy, a diversified firm is more likely to benefit from the policy. Diversified firms should perform better than non-diversified firms, and the positive relationship between diversification level and performance should be strengthened during an economy-wide crisis.

In addition, we conducted several robustness checks and explored channels through which diversified firms had better performance during crisis than their focused counterparts, such as bank loans and government stimulus packages.

The relationship between diversification and firm performance is unclear. Some researchers have found a positive and significant relationship and others note a negative and significant relationship. Other researchers did not find any significant effect. Moreover, many of these studies had sample selection biases.

Such a complicated situation calls for a contingency approach. One perspective of the contingency approach is to consider different institutional environments. An institution-based view (IBV) suggests that firms incur higher transaction costs in institutionally weaker environments than in institutionally stronger environments. By diversifying, firms create internal markets that may be more effective than inefficient external markets. Diversification can thus be a useful strategy to address market imperfections in institutionally weak environments.

\section{Test for Hypothesis}

Using data from a recent survey, we studied nearly 400 Nigeria private firms using two different approaches panel and cross-period comparisons. The findings of both approaches show that diversified firms performed better than focused firms. This was also true during the 2008 global financial crisis. The higher the diversification level, the more positive the firm performance was. We also investigated the influence of ownership structure. Firms that are totally owned by the founding owner and his/her family tend to have unsatisfactory performance under crisis. This finding provides evidence of the increasing attention on management and governance to explain firm.

Linear regression models were evaluated to test the effect of diversification on firm performance. Panel A uses profit as the dependent variable, and Panel B uses sales. For each year (2007, 2008, and 2009), two regression models were evaluated: one testing the impact of diversification and the other testing the impact of the diversification level. 
Panel A shows a diversification premium for Nigerian private firms, as diversification has a significant $(\mathrm{p} \leq$ $0.01)$ and positive impact on profit in each year. The diversification level also shows a significant $(\mathrm{p} \leq 0.01)$ and positive relationship with profit in all three models. Thus, Hypotheses $1 \mathrm{a}$ and $1 \mathrm{~b}$ are supported.

Checking the trend in the predictive power of diversification from 2007 to 2009, the coefficient of the diversification term decreased from 0.050 to 0.044 from 2007 to 2008, but it increased again to 0.058 in 2009. A similar trend was observed for the diversification level. Further statistical tests (results not shown) demonstrate that the differences in diversification level between 2009 and 2008 and 2009 and 2007 are significant. For diversification, the difference between 2009 and 2007 is significant, but the difference between 2009 and 2008 is not.

\section{Table 1: Descriptive statistics in Study 1}

\begin{tabular}{|c|c|c|c|c|c|}
\hline \multicolumn{6}{|c|}{ Std. } \\
\hline Variable & \begin{tabular}{|c} 
Observati \\
ons
\end{tabular} & Mean & deviation & Minimum & Maximum \\
\hline \multicolumn{6}{|l|}{ Dependent variables } \\
\hline 2007 sales & 3459 & 6843.43 & 56551.27 & 0.00 & 2587117.00 \\
\hline 2008 sales & 3459 & 8332.88 & 70785.86 & 0.00 & 3032710.00 \\
\hline 2009 sales & 3459 & 9739.12 & 98977.90 & 0.00 & 3942532.00 \\
\hline 2007 profit & 3459 & 388.04 & 2321.73 & 2000.00 & 59298.00 \\
\hline 2008 profit & 3459 & 455.46 & 2890.19 & 4000.00 & 76652.00 \\
\hline 2009 profit & 3459 & 541.41 & 3739.64 & 8402.00 & 136566.00 \\
\hline \multicolumn{6}{|l|}{ Independent variables } \\
\hline Diversification & 3459 & 0.23 & 0.42 & 0.00 & 1.00 \\
\hline Diversification level & 3459 & 1.31 & 0.61 & 1.00 & 3.00 \\
\hline \multicolumn{6}{|l|}{ Firm attributes } \\
\hline Firm age & 3267 & 8.19 & 4.41 & 0.00 & 20.00 \\
\hline Firm size & 3391 & 3.89 & 1.61 & 0.00 & 9.04 \\
\hline Leverage & 2336 & 0.22 & 0.28 & 0.00 & 1.00 \\
\hline $\mathrm{R} \& \mathrm{D}$ intensity & 3093 & 0.18 & 5.76 & 0.00 & 300.00 \\
\hline \multicolumn{6}{|l|}{ Firm owner attributes } \\
\hline Owner age & 3432 & 45.27 & 8.59 & 18.00 & 92.00 \\
\hline Education level & 3398 & 3.84 & 1.10 & 1.00 & 6.00 \\
\hline Former government cadre & 3459 & 0.14 & 0.34 & 0.00 & 1.00 \\
\hline Former SOE manager & 3459 & 0.06 & 0.23 & 0.00 & 1.00 \\
\hline $\mathrm{PC}$ & 3459 & 0.23 & 0.42 & 0.00 & 1.00 \\
\hline CPPCC & 3459 & 0.32 & 0.47 & 0.00 & 1.00 \\
\hline \multicolumn{6}{|l|}{ Regional attributes } \\
\hline 2007 market index & 3458 & 8.02 & 1.93 & 1.63 & 10.92 \\
\hline 2008 market index & 3458 & 8.31 & 1.95 & 1.36 & 11.16 \\
\hline 2009 market index & 3458 & 8.61 & 2.19 & 0.38 & 11.80 \\
\hline
\end{tabular}


Table 2: Descriptive statistics in Study 2

\begin{tabular}{|c|c|c|c|c|c|}
\hline Variable & Observations & Mean & Std. deviation & Minimum & Maximum \\
\hline \multicolumn{6}{|l|}{ Dependent variable } \\
\hline Profit yearly change & 6918 & 69.46 & 1152.31 & 21754.00 & 59914.00 \\
\hline \multicolumn{6}{|l|}{ Independent variables } \\
\hline Crisis dummy & 6918 & 0.50 & 0.50 & 0.00 & 1.00 \\
\hline Diversification & 6918 & 0.23 & 0.42 & 0.00 & 1.00 \\
\hline Diversification level & 6918 & 1.31 & 0.61 & 1.00 & 3.00 \\
\hline Family ownership & 3459 & 0.51 & 0.50 & 0.00 & 1.00 \\
\hline \multicolumn{6}{|l|}{ Firm's attributes } \\
\hline Firm age & 6533 & 8.19 & 4.41 & 0.00 & 20.00 \\
\hline Firm size & 6782 & 3.89 & 1.61 & 0.00 & 9.04 \\
\hline Leverage & 4670 & 0.22 & 0.28 & 0.00 & 1.00 \\
\hline $\mathrm{R} \& \mathrm{D}$ intensity & 6185 & 0.18 & 5.76 & 0.00 & 300.00 \\
\hline \multicolumn{6}{|l|}{ Firm owner attributes } \\
\hline Owner age & 6864 & 45.27 & 8.60 & 18.00 & 92.00 \\
\hline Education level & 6796 & 3.84 & 1.10 & 1.00 & 6.00 \\
\hline Former government cadre & 6918 & 0.14 & 0.34 & 0.00 & 1.00 \\
\hline Former SOE manager & 6918 & 0.06 & 0.23 & 0.00 & 1.00 \\
\hline $\mathrm{PC}$ & 6918 & 0.23 & 0.42 & 0.00 & 1.00 \\
\hline CPPCC & 6918 & 0.32 & 0.47 & 0.00 & 1.00 \\
\hline \multicolumn{6}{|l|}{ Regional attributes } \\
\hline 2009 market index & 6916 & 8.61 & 2.18 & 0.38 & 11.80 \\
\hline
\end{tabular}

Tables 1 and 2 summarize the descriptive statistics for the variables in Studies 1 and 2. Tables present their inter-correlation. The data fulfill the basic statistical assumptions justifying further analysis. For Study 1, the matrix in Table 1 shows that some variables were highly correlated but they were in different regression models. For Study, the matrix in Table above shows only diversification and the diversification level to be highly correlated $(\mathrm{r}>0.80)$, but they were also in different regression models. Overall, there was no substantial problem with multi-co-linearity among the independent and control variables. Furthermore, multi-co-linearity tests were conducted with each regression model, and the variance inflation factor was small $(<5)$ in every model. Firm size was always positively and significantly correlated with firm performance, and being a former SOE manager showed a significant negative relationship in some models.

\section{Discussion and Finding}

These findings reveal that, during a crisis, diversification usefully predicts firm performance, and the positive relationship of the diversification level with performance becomes more significant.

Panel B uses sales as the dependent variable, and the results are consistent with those in Panel A. For the control variables, firm size is always positively and significantly related to firm performance. Leverage, 
owner education, market index, and Nigeria chambers of commerce and industry are significant in some models and in agreement with the findings of previous studies.

This study investigates the relationship between diversification and the performance of Nigeria private firms during a global economic crisis. The results extend earlier research on diversification and performance by introducing the effects of abrupt institutional change. Using a large dataset of Nigeria private firms, we found that diversified firms performed better than focused firms during crises; more diversified firms performed better. Moreover, family ownership is negatively related to performance during a crisis. Owing to poor governance and management, limited resources, and external relationships, diversified firms that are totally owned by the founding owner and his/her family will perform unsatisfactorily in a crisis.

\subsection{Implication of Finding}

The results are robust considering different dependent variables, sub-samples, and causality testing. The importance of bank loan and government stimulus pack-ages is confirmed. The results indicate that diversification created value for Nigeria private firms during the 2008 global financial crisis.

The design of this study shows how use of an appropriate research setting can enhance theory testing. Owing to the nature of an economic crisis, firms do not have time to adjust their strategies. This setting allows for a clearer comparison between diversified and focused firms with fewer endogeneity and self-selection problems. Ownership may be endogenous but the ownership structure is quite stable for Nigeria private firms.

This paper provides empirical evidence of Nigeria private firms' diversification performance under crisis. The literature discussing diversification performance under crisis is limited, and to our knowledge, this paper is the first to discuss diversification performance during an economic crisis using data from Nigeria private firms.

\section{Conclusion}

The findings show that family ownership negatively impacts firm performance in a crisis. However, owing to data limitations, entropy and other popular measures of diversification could not be used. The findings are concerned with unrelated diversification and likely underestimate the effects of diversification. Future studies using different measures of diversification are needed to verify the findings. Furthermore, it will be useful to explore the financial resources, $R \& D$ investment, and corporate information systems to discover the key differences between diversified and focused firms and to elucidate the complex issues of diversification and firm performance.

\section{Recommendations}

In the light of the above findings, the study recommends that government should use its fiscal policy leverage to address the alarming infrastructure (roads, telecommunications, railways, electricity, etc.) deficit in the country. Similar interventions are required to strengthening the various institutions in the country. The aggregate impact of these measures would ensure a drastic cut in the cost of doing business in Nigeria. SMEs should also initiate sound HRMP in recruitment and selection, rewards and compensations processes. Besides relying on government handouts in the form of short term loans.

\section{References}

[1.] Chakrabarti, A., K. Singh, and I. Mahmood, 2007, Diversification and performance: Evidence from East Asian firms, Strategic Management Journal 28, pp. 101-120.

[2.] Dimitrov, V., and S. Tice, 2006, Corporate diversification and credit constraints: Real effects across the business cycle, The Review of Financial Studies 19, pp. 1465-1498.

[3.] Kuppuswamy, V. Serafeim, G. and Villalonga, B., (2012), 'The effect of institutional factors on the value of corporate diversification', Harvard Business School working paper, nr 13-022.

[4.] Lewellen, W.G., (1971), 'A pure financial rationale for the conglomerate merger', Journal of Finance, Vol. 26 (2), pp. 521-537.

[5.] Lubatkin, M. H., and S. Chatterjee, 1994, Extending modern portfolio theory into the domain of corporate diversification: Does it apply?, Academy of Management Journal 37, pp. 109-136.

[6.] Pearson, C. M., and J. Clair, 1998, Reframing crisis management, Academy of Management Review 23, pp. 59-76. 
[7.] Rudolph, C. and Schwetzler, B., (2013), 'Conglomerates on the rise again? A cross-regional study on the impact of the 2008-2009 financial crises on the diversification discount', Journal of Corporate Finance, Vol. 22, pp. 153-165.

[8.] Vaaler, P. M., and G. McNamara, 2004, Crisis and competition in expert organizational decision making: Credit-rating agencies and their response to turbulence in emerging economies, Organization Science 15, pp. 687-703. 